\title{
TAKAFUL KEBAKARAN SEBAGAI ALTERNATIF MEKANISME GANTI RUGI BAGI PEDAGANG DI PASAR TRADISIONAL DAN MODEL JARINGAN PENYEBARANNYA
}

\author{
Bagus Ananda Kurniawan \\ Dosen Program Studi Administrasi Publik/Negara \\ Fakultas Ilmu Sosial Dan Ilmu Politik Universitas Bhayangkara Surabaya \\ bagusanandakurniawan@gmail.com
}

\begin{abstract}
ABSTRAK
Konsep dan mekanisme operandi dalam Takaful Kebakaran sesuai dengan prinsip ekonomi Islam, karena Takaful Kebakaran menganut azas tolong menolong dengan membagi risiko diantara peserta asuransi (sharing of risk). Adanya Risk Sharing inilah cermin sikap tolong-menolong antara sesama seperti yang telah Rasulullah ajarkan kepada setiap umatnya. Mekanisme ganti rugi dalam Takaful Kebakaran tidak memberatkan pedagang, karena disesuiakan dengan kemampuan pedagang baik dari segi besarnya premi yang harus dibayar dan pemilihan jangka waktu pembayaran premi. Dalam penerapan Takaful Kebakaran juga tidak ada maisir, gharar dan riba yang masih ada pada asuransi kebakaran konvensional, yang telah dilarang Islam.

Berdasarkan pada permasalahan yang diangkat didalam penulisan ini maka metode penelitian yang digunakan adalah dengan pendekatan deskriptif kualitatif, yaitu suatu metode dalam meneliti status seseorang, suatu objek, suatu situasi atau kondisi sistem pemikiran. Pengembangan model jaringan penyebaran Takaful Kebakaran melalui konsep jaringan sosial merupakan refleksi dari pembangunan jaringan yang dilaksanakan Rasulullah ketika membina masyarakat Islam di Madinah, sehingga informasi dapat disebarkan secara efektif. Hal ini dapat dilihat dari pemilihan tempat jaringan berkomunikasi, peran pemimpin, dan hubungan antara anggota jaringan dan juga hubungan dengan pihak luar yang dapat mendukung tersebarnya informasi.
\end{abstract}

\section{Kata Kunci : Takaful Kebakaran, Pedagang Pasar Tradisional}

\section{ABSTRACT}

The concept and mechanisms of operation in accordance with the Fire Takaful Islamic economic principles, because the Fire Takaful adheres to the principles of helping to share the risk among insurance participants (sharing of risk). The existence Risk Sharing this attitude mirrors mutual help between fellow like that had the Prophet taught each of his people. Compensation mechanism in not burdening Fire Takaful traders, as adjusted by the ability of traders both in terms of the amount of premium to be paid and the premium payment term elections. In the application of Takaful Fire also no gambling, and usury gharar that still exist in the conventional fire insurance, which has been banned Islam.

Based on the issues raised in this study, the research method used is descriptive qualitative approach, a method in researching the status of a person, an object, a situation or a condition system of thought. Development of network model Takaful Fire spread through the concept of social networking is a reflection of the development of the 
network carried the Prophet when fostering Islamic community in Medina, so that information can be disseminated effectively. It can be seen from the selection of a communication network, the role of the leader, and the relationship between members of the network and relationships with outside parties that support the spread of information.

\section{Keywords: Takaful Kebakaran, Traditional Market Traders}

\section{A. PENDAHULUAN}

Melihat banyaknya kejadian kebakaran di pasar tradisional yang akhirakhir ini sering terjadi, dan akibat yang ditimbulkannya begitu luas bahkan dapat mengganggu stabilitas perekonomian negara, maka diperlukan suatu upaya preventif untuk menghadapi risiko kebakaran, yaitu dengan asuransi. Dengan berasuransi, masyarakat diharapkan akan selalu siap terhadap kejadian-kejadian yang tidak diinginkan yang menimpa usahanya. Sehingga jika terjadi kebakaran di pasar, pedagang tersebut masih mempunyai jaminan dari asuransi berupa dana pembayaran klaim. Dana klaim tersebut yang dapat digunakan oleh pedagang untuk memulai kembali usahanya, sehingga tetap ada yang menopang kehidupan mereka. Jika terjadi kebakaran di pasar, sedangkan pedagang tidak berasuransi, maka mereka akan kesulitan untuk kembali memulai usaha sehingga mengancam keberlangsungan usaha mereka.

Sebagian besar pedagang pasar sebenarnya sudah mengenal asuransi kerugian untuk kejadian kebakaran yang merupakan bagian dari asuransi konvensional. Asuransi kebakaran konvensional yang dikenal dan digunakan masyarakat, khususnya pedagang pasar dirasa masih menimbulkan permasalahanpermasalahan yang dapat merugikan peserta asuransinya. Hal ini dikarenakan tingginya tolakan klaim dan kurangnya pelayanan yang diberikan oleh perusahaan asuransi konvensional. Tercatat sejak September 2006, terdapat 70 kasus klaim asuransi yang ditolak (www.bmaindo.com). Selain itu, setelah kebakaran kedua tahun 1978, banyak pedagang Pasar Turi mengeluhkan soal biaya asuransi kebakaran yang seharusnya menjadi hak mereka tak kunjung mereka dapatkan. (www.kompas.com). Tingginya kasus penolakan klaim dan tidak maksimalnya pelayanan oleh perusahaan asuransi ini, membuat perlindungan nasabah sebagai pihak konsumen semakin terabaikan.

Kompleksitas permasalahan yang terdapat pada asuransi kebakaran konvensional, membuat masyarakat dalam hal ini pedagang, membutuhkan asuransi yang benar-benar memberikan perlindungan; adil dan transparan. Takaful Kebakaran dapat menjadi alternatif yang tepat sebagai bentuk usaha preventif untuk kemungkinan kerugian yang timbul dari bencana kebakaran. Hal ini karena Takaful Kebakaran memiliki kelebihankelebihan jika dibandingkan dengan asuransi kebakaran konvensional yaitu terutama dilihat dari segi pengelolaan risiko. Pengelolaan risiko asuransi konvensional berupa transfer risiko dari para peserta kepada perusahaan asuransi (transfer of risk) sedangkan asuransi syariah menganut azas tolong menolong 
dengan membagi risiko diantara peserta asuransi (sharing of risk) yang sesuai dengan prinsip tolong menolong dalam Islam.

\section{Takaful Kebakaran cocok} digunakan bagi pedagang di pasar tradisional karena besar premi yang harus dibayar disesuaikan dengan kemampuan masing-masing dan juga dalam praktiknya yang tidak menerapkan riba, maisir dan gharar seperti yang masih terdapat pada asuransi kebakaran konvensional, sehingga Takaful Kebakaran ini sesuai dengan syariah Islam, karena Islam dengan tegas menolak adanya riba dalam setiap usaha umatnya, hal ini seperti yang tercantum dalam Q.S. Al-Baqarah ayat 275 yang mengandung arti, "Orang-orang yang memakan riba tidak dapat berdiri melainkan seperti berdirinya orang yang kemasukan setan karena gila. Yang demikian itu karena mereka berkata bahwa jual beli sama dengan riba. Padahal, Allah telah menghalalkan jual beli dan mengharamkan riba".

Meskipun demikian, pada kenyataanya Takaful Kebakaran belum begitu dikenal bagi sebagian besar masyarakat Indonesia, padahal mayoritas penduduknya beragama Islam. Mengingat kios usaha pedagang di pasar tradisional yang rentan terhadap kebakaran karena kurangnya fasilitas pemadam kebakaran dan seringnya peristiwa kebakaran pasar yang terjadi, maka diperlukan suatu bentuk sosialisasi Takaful Kebakaran agar dikenal dan dapat dimanfaatkan secara optimal untuk mencegah akibat kerugian kebakaran yang tidak terduga. Upaya sosialisasi Takaful kebakaran membutuhkan komunikasi yang efektif agar masyarakat dapat menerima dan mendukung perkembangannya dalam rangka menciptakan stabilitas perekonomian negara. Al-Qur'an sebagai kitab suci agama Islam sesungguhnya telah mengatur tentang upaya-upaya muamalah sebagai bentuk komunikasi yang efektif, yaitu melalu konsep jaringan dan silaturahmi.

Konsep jaringan dan silaturahmi ini dapat dimulai melalui suatu pusat pertemuan seperti yang telah Rasulullah lakukan pada masanya. Setelah Rasulullah hijrah dari Mekkah ke Madinah, yang pertama dilakukan ketika tiba di Madinah adalah dengan mendirikan masjid untuk mensyi'arkan agama Islam di Madinah. Beliau mengutamakan pendirian masjid terlebih dahulu dari pada mendirikan bangunan apaupun selain rumah tinggalnya sendiri. Hal ini karena masjidlah yang akan menjadi tempat pertemuan banyak umat sebagai persinggahan ketika sholat ataupun istirahat. Inilah yang kemudian dimanfaatkan Rasulullah untuk menyebarluaskan ajaran Islam kepada masyarakat luas.

Konsep pusat pertemuan yang dibangun Rasulullah ini dapat dijadikan sebagai cerminan dalam usaha komunikasi dalam rangka sosialisasi Takaful Kebakaran kepada masyarakat khususnya pedagang di pasar tradisional. Dengan memanfaatkan pusat pertemuan para pedagang di pasar tradisional, yaitu asosiasi pedagang pasar, informasiinformasi Takaful Kebakaran ini dapat disebarluaskan secara langsung maupun tidak langsung. Dengan cara seperti ini, maka tidak hanya bermanfaat sebagai penyebar informasi tetapi juga sebagai 
sarana silaturahmi yang akan memperkuat ukhuwah islamiah antar masyarakat khususnya pedagang di pasar tradisional. Hal tersebut di atas yang menjadi landasan bagi penulis dalam menyusun karya tulis ilmiah ini dengan judul "Takaful Kebakaran sebagai Alternatif Mekanisme Ganti Rugi Bagi Pedagang di Pasar Tradisional dan Model Jaringan Penyebarannya".

\section{B. LITERATUR REVIEW}

Evaluasi Mekanisme Pengelolaan Dana dengan Sistem Mudharabah pada Asuransi Syariah (Studi Kasus pada PT. Asuransi Takaful Keluarga Cabang Makassar) penulis Andi Sriwahyuni Jurusan Akuntansi Fakultas Ekonomi dan Bisnis Universitas Hasanuddin, Tujuan dari penelitian ini adalah untuk mengetahui kesesuain mekanisme pengelolaan dana pada Asuransi Takaful Keluarga berdasarkan dengan prinsipprinsip syariah maupun dengan PSAK 105.

Data penelitian ini diperoleh dari observasi dan wawancara langsung dengan pihak yang terkait dengan PT. Asuransi Takaful Keluarga Cab. Makassar. Metode analisis yang digunakan dalam penelitian ini adalah deksriptif komparatif. Hasil analisis dari penelitian ini adalah mekanisme pengelolaan dana dengan sistem mudharabah pada PT Asuransi Takaful keluarga cab.Makassar dengan prinsip syariah yang ada dalam fatwa DSN No 21/DSN-MUI/2001 pada dasarnya telah sesuai namun hanya terdapat perbedaan pemakain istilah akad demikian pula dari segi pengelolaan dana berdasarkan PSAK 105 telah sesuai dengan yang diterapkan pada PT. Asuransi Takaful Keluarga yakni ketika terjadi keuntungan pemegang polis akan mendapatkan bagi hasil sesuai dengan rasio kesepakatan diawal sedangkan ketika terjadi kerugian akan ditanggung pemilik dana.

Perbandingan hasil penelitian dari Triana Agus Gozali Jurusan Muamalat Fakultas Syariah Dan Hukum Universitas Islam Negeri Sunan Kalijaga Yogyakarta 2010 yang berjudul Faktor - Faktor Yang Mempengaruhi Pengambilan Keputusan Beli Jasa Asuransi Takaful Dana Pendidikan (FULNADI) Studi kasus pada Nasabah PT. Asuransi Takaful Keluarga Cabang Yogyakarta) dapat disimpulkan bahwa faktor-faktor yang mempengaruhi pengambilan keputusan beli jasa asuransi takaful dana pendidikan, yaitu berupa motivasi, kelas sosial, dan pelayanan secara parsial maupun simultan.

Untuk mengetahui pengaruh secara simultan digunakan uji $\mathrm{F}$ dan untuk mengetahui pengaruh secara parsial digunakan uji t. Metode analisis yang digunakan untuk menguji hipotesis adalah analisis regresi berganda dengan terlebih dahulu melakukan uji asumsi klasik. Hasil penelitian menunjukkan bahwa secara simultan ketiga faktor yaitu motivasi, kelas sosial dan pelayanan dapat berpengaruh secara signifikan terhadap keputusan beli. Secara parsial variabel independen yang berpengaruh signifikan terhadap keputusan beli adalah motivasi dan pelayanan. Sedangkan variabel yang tidak berpengaruh signifikan secara parsial adalah kelas sosial.

\section{METODE PENULISAN}

Berdasarkan pada permasalahan yang diangkat didalam penulisan ini maka 
metode penelitian yang digunakan adalah dengan pendekatan deskriptif kualitatif, yaitu suatu metode dalam meneliti status seseorang, suatu objek, suatu situasi atau kondisi sistem pemikiran.

\section{PEMBAHASAN}

1. Gambaran Umum Konsep dan Mekanisme Operandi Asuransi Syariah (Takaful) di Indonesia

Takaful yang berarti saling menanggung antar-umat manusia merupakan dasar pijakan kegiatan manusia sebagai makhluk sosial. Atas dasar pijakan tersebut, di antara peserta bersepakat menanggung bersama diantara mereka atas risiko yang diakibatkan oleh kematian, kebakaran, kehilangan, dan sebagainya. Dengan demikian, sistem asuransi syariah harus bersifat universal, berlaku secara umum (Amrin: 2006).

Takaful atau lebih dikenal dengan istilah asuransi syariah, dalam pengertian mu'amalah berarti saling menanggung risiko diantara sesama manusia sehingga antara satu dan yang lain menjadi penanggung atas risiko yang lain. Berikut ini disajikan suatu bagan yang dapat memperjelas perbedaan antara risk transfer yang berlaku pada asuransi konvesional dan risk sharing yang dilaksanakan pada asuransi syariah (Iqbal, 2006:4).

Sedangkan pada prinsip risk sharing pada asuransi syariah (takaful), risiko dibagikan kepada seluruh peserta asuransi syariah sedangkan perusahaan asuransi syariah hanya bertindak sebagai operator takaful. Dana yang terkumpul dari peserta diniatkan untuk tolong menolong diantara peserta bila terjadi musibah, dalam hal ini tidak terjadi pengalihan kepemilikan dana atau pooling of fund dan asuransi syariah hanya bertindak sebagai pengelola dana yang dipercayakan oleh para peserta. Misalnya, ketika seorang peserta mengikuti asuransi kebakaran untuk rumah tinggal, maka orang tersebut akan memberikan kontribusi dana (premi) sebesar nilai yang telah ditentukan oleh perusahaan asuransi syariah yang diniatkan untuk saling tolong-menolong diantara peserta.

Perusahaan asuransi syariah akan memasukkan dana tersebut ke suatu rekening khusus (kumpulan dana peserta), bila terjadi kebakaran atas rumah tinggal tersebut maka perusahaan (sebagai wakil dari peserta) akan mengambil dana dari rekening khusus tersebut dan memberikannya kepada peserta yang terkena musibah, namun bila tidak terjadi musibah kebakaran terhadap tempat tinggal peserta dan masih ada kelebihan dana pada rekening khusus tersebut, maka ada pengembalian yang berupa surplus sharing

(www.asuransiresikosyariah.com).

Konsep risk sharing inilah yang menjadi wujud nyata tolong menolong antar umat dalam asuransi syariah (Takaful). Bentuk Risk sharing pada asuransi syariah diwujudkan melalui dana tabarru', yaitu kumpulan dana peserta yang disatukan dalam rekening khusus dan oleh peserta ditujukan sebagai rekening derma yaitu rekening yang digunakan untuk saling membantu diantara peserta asuransi syariah. Dana ini dikelola dengan akad mudharabah yaitu dengan bagi hasil. Asuransi syariah tidak menggunakan sistem bunga seperti pada asuransi konvensional karena dianggap 
mengandung unsur riba yang diharamkan dalam ajaran Islam

Dalam asuransi syariah (takaful) para peserta asuransi syariah berkedudukan sebagai pemilik modal dan perusahaan asuransi syariah berfungsi sebagai yang menjalankan modal, hal tersebut merupakan salah satu faktor yang dapat mencegah timbulnya dana hangus. Keuntungan yang diperoleh dari pengembangan dana milik peserta itu dibagi antara para peserta dan perusahaan sesuai ketentuan yang telah disepakati. Terdapat dua mekanisme pengelolaan dana peserta (premi), yang pertama ialah melalui sistem yang mengandung unsur tabungan dan yang kedua adalah sistem yang tidak mengandung unsur tabungan atau disebut juga rekening tabarru'.

$$
\text { Mekanisme sistem yang }
$$
mengandung unsur tabungan adalah dimana setiap peserta wajib membayar sejumlah uang (premi) secara teratur kepada perusahaan. Besar premi yang akan dibayarkan tergantung kepada kemampuan peserta. Akan tetapi perusahaan menetapkan jumlah minimum premi yang dapat dibayarkan. Setiap peserta dapat membayar premi tersebut melalui rekening koran, giro atau membayar langsung. Peserta dapat memilih cara pembayaran baik tiap bulan, kuartal, semester maupun tahunan. Setiap premi yang dibayar oleh peserta akan dipisah oleh perusahaan asuransi syariah (takaful) dalam dua rekening yang berbeda, yaitu rekening tabungan dan rekening tabarru'. Rekening tabungan yaitu kumpulan dana yang merupakan milik peserta, yang dibayarkan bila perjanjian berakhir, peserta mengundurkan diri dan ketika peserta meninggal dunia Sedangkan Rekening Tabarru' adalah kumpulan dana yang diniatkan oleh peserta sebagai iuran kebajikan untuk tujuan saling tolongmenolong dan saling membantu, yang dibayarkan apabila peserta meninggal dunia dan ketika perjanjian telah berakhir dan jika ada surplus dana. Sedangkan sistem yang tidak mengandung unsur tabungan hanya terdiri dari rekening tabarru'.(www.infoasuransisyari'ah.com.

Kumpulan dana peserta ini akan diinvestasikan sesuai dengan syariah Islam. Keuntungan dari hasil investasi setelah dikurangi dengan beban asuransi (klaim dan premi re-asuransi), akan dibagi antara peserta dan perusahaan menurut akad mudharabah dalam suatu perbandingan tetap berdasarkan perjanjian kerjasama antara perusahaan dengan peserta. Akad mudharabah ini berbeda dengan sistem bunga mengingat sifat pengembalian (return) yang tidak pasti baik dari segi jumlah maupun segi waktu. Dalam bahasa lain, produk ini disebut juga dengan Trust Financing atau Trust Investment karena kontrak ini hanya diberikan kepada pengusaha yang benarbenar credible dan sudah teruji amanahnya.

2. Takaful Kebakaran sebagai Alternatif Mekanisme Ganti Rugi bagi Pedagang di Pasar Tradisional

Menurut Keputusan Menteri Keuangan yang menyatakan bahwa pedagang yang termasuk dalam usaha mikro berpenghasilan maksimal seratus juta dalam satu tahun merupakan suatu pertanda bahwa takaful kebakaran dapat menawarkan suatu bentuk perlindungan yang preminya dapat disesuaikan dengan kemampuan peserta takaful, karena di 
dalamnya tidak dimasukkan unsur bunga, namun digantikan oleh bagi hasil yang telah diketahui dan disepakati oleh kedua belah pihak.

Dengan demikian premi dirasa tidak memberatkan pihak pedagang, karena jika pada pertengahan reversing period pedagang menginginkan keluar dari takaful kebakaran maka premi yang telah mereka bayar dapat dikembalikan tanpa ada dana hangus. Dan apabila hingga jatuh tempo kios mereka tidak terbakar dan tidak menimbulkan suatu klaim maka premi yang telah mereka bayarkan akan dikembalikan beserta surplus sharing, jika ada. Mekanisme ganti rugi yang dilakukan oleh takaful kebakaran berbeda dengan asuransi kerugian kebakaran konvensional dimana dalam asuransi kebakaran konvensional jika tidak terjadi kebakaran dan tidak ada klaim maka premi yang selama ini telah dibayar tidak dapat dikembalikan kepada peserta karena telah menjadi milik perusahaan.

Pembayaran ganti rugi atas kerugian yang diderita pedagang adalah senilai dengan uang pertanggungan yang telah disepakati oleh kedua belah pihak atau dibawah dari jumlah yang dipertanggungkan. Apabila kerugian melebihi taksiran semula maka pihak asuransi tidak akan mengganti kelebihan tersebut. Untuk menghindari adanya tolakan klaim bagi peserta asuransi maka pihak takaful kebakaran mempersiapkan dana cadangan serta mengikuti reasuransi guna mencegah adanya klaim yang tidak terbayar. Namun, takaful kebakaran juga memiliki kelemahan, takaful kebakaran dalam perhitungannya membutuhkan data secara rinci mengenai barang-barang yang dimiliki oleh pedagang sebagai pemilik toko sedangkan pedagang di pasar mayoritas tidak melakukan pembukuan atau pencatatan dengan baik. Dengan demikian pihak takaful kebakaran yang aktif dalam melakukan follow up ataupun memperketat pengawasan terhadap kondisi pedagang di pasar tradisional tersebut (www.vibiznews.com).

Bentuk perlindungan yang diperlukan oleh pedagang di pasar tradisional dalam mewaspadai adanya kemungkinan kebakaran ini, kurang mendapat perhatian dari pemerintah, seperti halnya asuransi syariah, takaful kebakaran yang termasuk di dalamnya juga hanya diawasi oleh Dewan Syariah Nasional namun hal tersebut kurang menguatkan posisi takaful kebakaran di masyarakat, apabila pemerintah dapat mengupayakan hal tersebut maka suatu jalan pembuka bagi takaful kebakaran dan dapat memperkuat kepercayaan masyarakat dalam menanamkan dananya dalam rangka tolong-menolong untuk menghadapi risiko. 
Tabel 1. Perbedaan Mekanisme Pelaksaan Dalam Asuransi Konvensional dan Takaful Kebakaran

\begin{tabular}{|c|c|c|}
\hline Pembanding & $\begin{array}{c}\text { Asuransi Kebakaran } \\
\text { Konvensional }\end{array}$ & Takaful Kebakaran \\
\hline Premi & 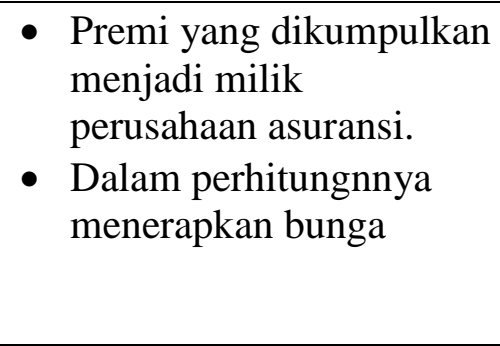 & $\begin{array}{l}\text { - Premi yang dikumpulkan } \\
\text { tetap merupakan milik } \\
\text { peserta, dan pihak asuransi } \\
\text { hanya sebagai pengelola. } \\
\text { - Dalam perhitungannya tidak } \\
\text { menerapkan bunga, tetapi } \\
\text { prinsip bagi hasil. }\end{array}$ \\
\hline Jika Terjadi Klaim & $\begin{array}{l}\text { Klaim akan ditanggung } \\
\text { sebesar kerugian sesuai } \\
\text { kesepakatan awal. } \\
\text { - Sumber dana klaim } \\
\text { berasal dari rekening } \\
\text { perusahaan }\end{array}$ & $\begin{array}{l}\text { - Klaim akan ditanggung } \\
\text { sebesar kerugian sesuai } \\
\text { kesepakatan awal, bisa lebih } \\
\text { rendah, tetapi tidak bisa lebih } \\
\text { tinggi. } \\
\text { - Sumber dana klaim berasal } \\
\text { dari premi peserta ditambah } \\
\text { tabarru dan ditambah juga } \\
\text { dengan surplus sharing } \\
\text { perusahaan jika ada. } \\
\end{array}$ \\
\hline $\begin{array}{l}\text { Jika Tidak Terjadi } \\
\text { Klaim }\end{array}$ & Dana hangus & $\begin{array}{l}\text { Premi yang sudah dibayar akan } \\
\text { dikembalikan setelah dipotong } \\
\text { dengan biaya operasional yang } \\
\text { wajar ditambah dengan surplus } \\
\text { sharing jika ada. }\end{array}$ \\
\hline Contoh Perusahaan & $\begin{array}{l}\text { PT. Allianz AG, PT Sinar } \\
\text { Mas, PT. Jasindo }\end{array}$ & PT. Asuransi Takaful Umum \\
\hline Bunga & $\begin{array}{l}\text { Dana sepenuhnya dimiliki } \\
\text { perusahaan, jadi perusahaan } \\
\text { mempunyai tanggungan } \\
\text { bunga yang diberikan setiap } \\
\text { tahun kepada peserta. }\end{array}$ & $\begin{array}{l}\text { Tidak ada bunga karena dana } \\
\text { yang dikelola perusahaan } \\
\text { menggunakan sistem bagi hasil, } \\
\text { jadi perusahaan tidak } \\
\text { mempunyai tanggungan bunga } \\
\text { kepada peserta. }\end{array}$ \\
\hline Kontrak & $\begin{array}{l}\text { Kontrak belum dijelaskan } \\
\text { secara rinci }\end{array}$ & Kontrak dijelaskan secara rinci \\
\hline
\end{tabular}

Sumber : Hasil Pengolahan dari Tim Penulis

Berdasarkan tabel di atas, takaful kebakaran dapat dijadikan sebagai alternatif mekanisme ganti rugi bagi pedagang di pasar tradisional. Hal ini dikarenakan uang pertanggungan yang dibayar berdasarkan klaim yang diajukan dapat digunakan sebagai modal awal untuk membuka usaha kembali apabila kerugian yang ditimbulkan oleh kebakaran tersebut berdampak besar. Rasa aman yang dirasakan pedagang karena adanya perlindungan terhadap risiko kebakaran melalui takaful kebakaran ini, dapat membuat para pedagang dapat berusaha 
lebih tenang sehingga roda ekonomi sektor menengah ke bawah dapat berjalan normal atau sebagaimana mestinya.

\section{Model Jaringan Penyebaran Takaful Kebakaran bagi Pedagang di Pasar Tradisional}

Konsep Takaful, khususnya Takaful Kebakaran dalam mekanisme ganti ruginya yang sesuai dengan syariat Islam memang memiliki kelebihankelebihan dibandingkan dengan asuransi kebakaran konvensional yang selama ini dikenal masyarakat. Namun dalam perkembangannya, Takaful Kebakaran belum menyentuh masyarakat yang seharusnya dapat memanfaatkannya, yaitu pedagang di pasar tradisionl yang akhirakhir ini membutuhkan asuransi kebakaran yang adil dan transaparan. Masalah utamanya adalah berkaitan dengan minimnya pengetahuan masyarakat secara luas mengenai asuransi, sehingga manfaat dan pentingnya asuransi bagi masyarakat tidak bisa tersampaikan. Oleh karena itu perlu keseriusan untuk bisa menangani masalah ini, yaitu dengan sosialisasi.

Keefektifan model jaringan sosial dalam menyebarluaskan informasi yang dilaksanakan Rasulullah inilah yang kemudian dapat kita jadikan refleksi dalam penyebaran Takaful Kebakaran kepada masyarakat, khususnya pedagang di pasar tradisional, yaitu melaui komunikasi formal dan komunikasi informal. Dalam penulisan ini, yang dimaksud dengan komunikasi formal adalah komunikasi yang direncanakan, diatur dan dilaksanakan secara sengaja untuk mencapai tujuan. Komunikasi formal ini terjadi antara pemerintah, perusahaan asuransi dan ketua asosiasi pedagang pasar, ataupun sosialisasi di dalam asosiasi itu sendiri Sedangkan komunikasi informal adalah komunikasi yang terjadi secara kebetulan, dan tidak direncanakan secara khusus. Komunikasi informal ini dilakukan oleh pedagang pasar dan pihak luar (masyarakat).

Keefektifan model jaringan sosial dalam menyebarluaskan informasi yang dilaksanakan Rasulullah inilah yang kemudian dapat kita jadikan refleksi dalam penyebaran Takaful Kebakaran kepada masyarakat, khususnya pedagang di pasar tradisional, yaitu melaui komunikasi formal dan komunikasi informal. Dalam penulisan ini, yang dimaksud dengan komunikasi formal adalah komunikasi yang direncanakan, diatur dan dilaksanakan secara sengaja untuk mencapai tujuan. Komunikasi formal ini terjadi antara pemerintah, perusahaan asuransi dan ketua asosiasi pedagang pasar, ataupun sosialisasi di dalam asosiasi itu sendiri Sedangkan komunikasi informal adalah komunikasi yang terjadi secara kebetulan, dan tidak direncanakan secara khusus. Komunikasi informal ini dilakukan oleh pedagang pasar dan pihak luar (masyarakat). 


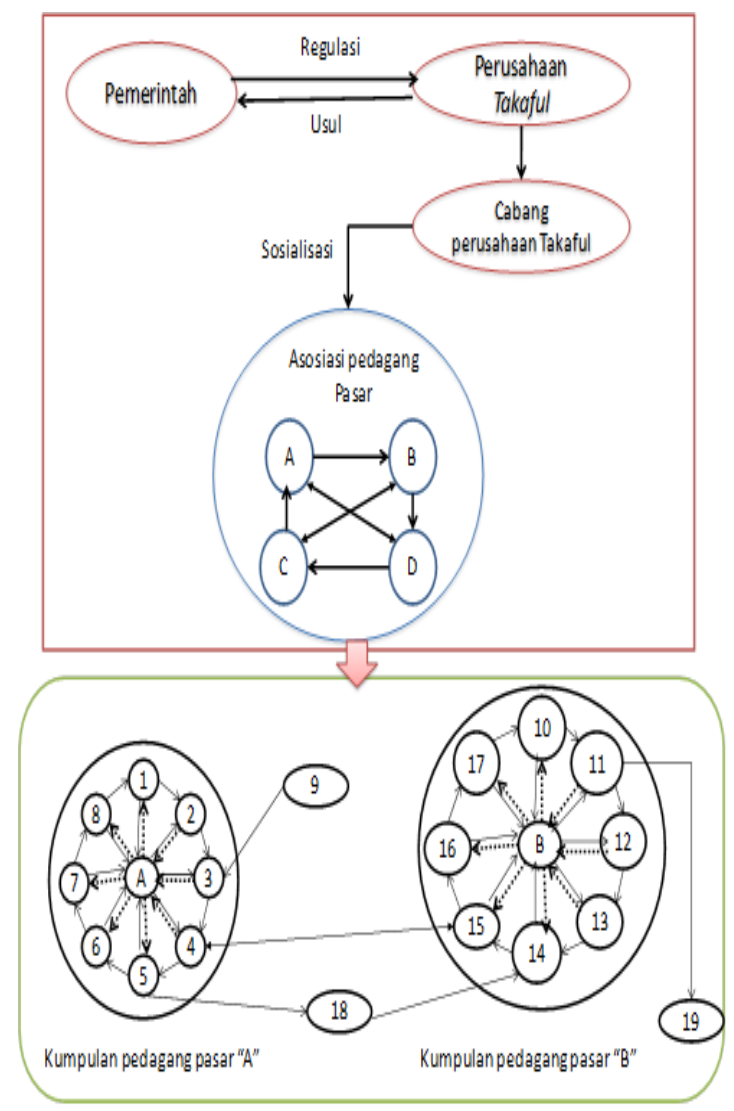

\section{Bagan 2. Model Jaringan Penyebarluasan Informasi Takaful Kebakaran Bagi Pedagang di Pasar Tradisional}

Bagan di atas memaparkan model jaringan penyebarluasan informasi Takaful Kebakaran yang melibatkan komunikasi formal dan informal. Langkah awal dimulai oleh perusahaan Takaful yang mengusulkan agar pemerintah segera merancang draft Undang-Undang tentang Takaful, termasuk pula produk-produk dari Takaful yang salah satunya ialah Takaful Kebakaran. Langkah tersebut diperlukan karena selama ini belum ada Undang-Undang yang mengatur tentang Takaful (Auransi Syariah), padahal keberadaan Undang-Undang tersebut dapat berperan sebagai pedoman bagi perusahaan Takaful untuk menjalankan kegiatannya. Ketika pemerintah telah mengeluarkan Undang-Undang tersebut, yang tentu dapat memperkuat keberadaan Perusahaan Takaful maupun pelaksanaannya, Perusahaan Takaful melalui cabangnya yang berada di wilayah tertentu mulai mengadakan sosialisasi terhadap perkumpulan ketua dan ataupun anggota asosiasi pedagang pasar di wilayah tersebut sebagai wakil dari masing-masing pasar (misal: pasar A, B, C dan D). Wakil dari masing-masing pasar (Ketua) yang terhimpun dalam Asosiasi Pedagang Pasar tersebut 
sebenarnya juga telah berkomunikasi untuk saling tukar informasi. Dengan adanya komunikasi antara (cabang) Perusahaan Takaful dengan Asosiasi Pedagang Pasar, maka kedua belah pihak tersebut dapat "sharing" tentang pentingnya Takaful Kebakaran sebagai alternatif mekanisme ganti rugi bagi pedagang di pasar tradisional.

Ketika sosialisasi dari (cabang) Perusahaan Takaful kepada para wakil dari Asosiasi Pedagang Pasar telah selesai, maka yang perlu dilakukan selanjutnya adalah sosialisasi kepada para pedagang pasar. Ketua dari masingmasing pasar menyebarluaskan informasi tentang pentingnya Takaful Kebakaran bagi para pedagang. Misal, ketua dari pasar A yang sebelumnya telah mengikuti sosialisai dari pihak Perusahaan Takaful, akan menyebarkan informasi tersebut kepada para pedagang di pasar A (nomor $1,2,3,4,5,6,7,8)$. Begitu pun yang terjadi pada kumpulan pedagang pasar B.

Informasi yang diperoleh dapat berasal dari pihak luar pasar, misal pada pasar A nomor 3, mendapat informasi dari pihak luar (9), sehingga pedagang (3) tersebut dapat pula menyebarluaskan informasi kepada anggota lainnya. Selain itu, kedekatan hubungan pasar A nomor 4 dengan padagang $\mathrm{B}$ nomor 15 menyebabkan keduanya dapat saling tukar informasi yang menyebabkan informasi yang diperoleh kedua belah pihak saling melengkapai. Dalam penyebarluasan informasi, pedagang di pasar A bisa saja memberi informasi kepada pihak luar (18), yang lalu pihak luar tersebut meneruskan informasi kepada pedagang di pasar B (14). Kemungkinan lain juga bisa saja muncul ketika pedagang di pasar B (11) memberikan informasi kepada pihak luar (19), sehingga pihak luar tersebut juga memperoleh informasi tentang Takaful Kebakaran.

Konsep jaringan sosial dalam menyebarluaskan Takaful Kebakaran yang dijelaskan melalui bagan di atas, merupakan refleksi dari apa yang Rasulullah laksanakan ketika membangun masyarakat Islam di Madinah. Dimana pada masa Rasulullah, masjidlah yang digunakan sebagai pusat pertemuan dan pusat berkembangnya berbagai informasi saat itu. Sedangkan pada konteks penyebaran Takaful Kebakaran ini, pasar melalui wadah Asosiasi Pedagang Pasar dijadikan sebagai pusat pertemuan dan juga pusat berkembangnya informasi tentang Takaful Kebakaran dikalangan pedagang di pasar tradisional tersebut. Peran pemimpin dalam jaringan sosial penyebaran Takaful Kebakaran ini, juga merupakan refleksi dari peran kepemimpinan Rasulullah ketika membangun jaringan dulu.

\section{E. KESIMPULAN}

Konsep dan mekanisme operandi dalam Takaful Kebakaran sesuai dengan prinsip ekonomi Islam, karena Takaful Kebakaran menganut azas tolong menolong dengan membagi risiko diantara peserta asuransi (sharing of risk). 
Adanya Risk Sharing inilah cermin sikap tolong-menolong antara sesama seperti yang telah Rasulullah ajarkan kepada setiap umatnya. Mekanisme ganti rugi dalam Takaful Kebakaran tidak memberatkan pedagang, karena disesuiakan dengan kemampuan pedagang baik dari segi besarnya premi yang harus dibayar dan pemilihan jangka waktu pembayaran premi.

Dalam penerapan Takaful Kebakaran juga tidak ada maisir, gharar dan riba yang masih ada pada asuransi kebakaran konvensional, yang telah dilarang Islam. Pengembangan model jaringan penyebaran Takaful Kebakaran melalui konsep jaringan sosial merupakan refleksi dari pembangunan jaringan yang dilaksanakan Rasulullah ketika membina masyarakat Islam di Madinah, sehingga informasi dapat disebarkan secara efektif. Hal ini dapat dilihat dari pemilihan tempat jaringan berkomunikasi, peran pemimpin, dan hubungan antara anggota jaringan dan juga hubungan dengan pihak luar yang dapat mendukung tersebarnya informasi.

\section{F. SARAN}

a) Pemerintah hendaknya segera melengkapi Undang-Undang mengenai perasuransian syariah serta Undang-undang yang menganjurkan setiap pengusaha untuk mengasuransikan usahanya, agar apabila terjadi suatu musibah tidak begitu berpengaruh terhadap stabilitas perekonomian.

$\begin{array}{lll}\text { b) Perusahaan } & \text { Asuransi } & \text { Syariah } \\ \text { hendaknya bekerja sama } & \text { dengan }\end{array}$ pihak pengelola pasar dalam upaya perlindungan pasar terhadap risiko kebakaran, demi menjaga kelangsungan perekonomian rakyat.

c) Hendaknya masyarakat khususnya pedagang pasar mulai menyadari dan menerapkan Takaful Kebakaran sebagai salah satu bentuk kewaspadaan atas risiko yang tidak terduga di masa yang akan datang dan juga bentuk pemanfaatan asuransi yang sesuai syariah Islam.

\section{DAFTAR PUSTAKA}

Amrin, Abdullah. 2006. Asuransi Syariah. Keberadaan dan Kelebihannya di Tengah Asuransi Konvensional. PT Elex Gramedia Computindo. Kelompok Gramedia: Jakarta

Effendy, Onong Uchjana. 1999. Ilmu Komunikasi, Teori, dan Praktek. Remaja Rosda Karya: Bandung

1986. Human

Relations dan Public Relations Dalam Management. Alumni: Bandung 1993. Dinamika Komunikasi. Remaja Rosdakarya: Bandung

Handayaningrat, S.. 1990. Pengantar Studi Ilmu Administrasi dan Manajemen. Haji Massagung: Jakarta

Hasan, Erliana. 2005. Komunikasi Pemerintahan. Refika Aditama: Bandung. 
Pratikno, Riyono. 1987. Berbagai Aspek Ilmu Komunikasi. Remadja Karya: Bandung

Rahardjo, M. Dawam. 1999. Islam dan Transformasi Sosial-Ekonomi. Pustaka Pelajar: Yogyakarta.

Rahman, N. Vinky. 2004. Kebakaran, Bahaya Unpredictible, Upaya Dan Kendala Penanggulangannya. Jurnal. Fakultas Teknik. Program Studi Arsitektur. Universitas Sumatera Utara.

Sudarsono, Heri. 2003. Bank dan Lembaga Keuangan Syariah. Deskripsidan Ilustrasi. CV Adipura: Yogyakarta.

Tim Dosen PAI Universitas Brawijaya. 2005. Pendidikan Agama Islam. Citra Mentari Group: Malang

Bulletin Fastco. Edisi Rabu, 3 Rabiul Akhir 1429 H/ 9 April 2005 